\title{
Perbandingan Kadar IL-1 $\alpha$ antara Tindakan Debridement Tajam Agresif dan Debridement Tajam Konservatif pada Penderita Kaki Diabetik
}

\author{
${ }^{1}$ Vincent D. Tjiptadi, ${ }^{2}$ Adrian Tangkilisan \\ ${ }^{1}$ PPDS Ilmu Bedah Fakultas Kedokteran Universitas Sam Ratulangi Manado \\ ${ }^{2}$ KSM Ilmu Bedah Divisi Bedah Toraks Kardiovaskular RSUP Prof. Dr. R. D. Kandou \\ Manado \\ Email: vincenttjiptadi@gmail.com
}

\begin{abstract}
Diabetic foot is a chronic complication of diabetes mellitus which is commonly found but very threatening due to its unsatisfied management, usually ended with amputation or death. Sharp debridement is the gold standard of diabetic foot, albeit, it has to be considered wisely due to the metabolic disorder, sepsis, and other comorbid factors of the patients. This study was aimed to compare the dynamics of Il- $1 \alpha$ levels in patients with aggresive sharp debridement and with conservative sharp debridement associated with clinical improvement. This was an experimental analytical study. There were 38 patients with diabetic foot admitted at Prof. Dr. R. D. Kandou Hospital Manado with an age range of 30-60 years, obtained by using simple random sampling. The patients were divided inti two groups: aggressive sharp debridement dan conservative sharp debridement, each of 19 patients. Samples for laboratory examination were collected before and after debridement. In consevative sharp debridement group, the mean levels of IL- $1 \alpha$ before treatment was $108,158 \pm 14,519 \mathrm{pg} / \mathrm{ml}$ meanwhile after treatment was $108,526 \pm 16,625 \mathrm{pg} / \mathrm{ml}$ that showed no significant elevation. In aggressive sharp debridement group, the mean levels of IL- $1 \alpha$ before treatment was 93,263 $\pm 15,172 \mathrm{pg} / \mathrm{ml}$ meanwhile after treatment was $104,052 \pm 18,807 \mathrm{pg} / \mathrm{ml}$ that showed a significant elevation. Conclusion: In patients with diabetic foot, elevation of IL- $\alpha$ levels after aggressive sharp debridement was greater than after conservative sharp debridement.
\end{abstract}

Keywords: diabetic foot, sharp debridement, interleukin 1- $\alpha$

\begin{abstract}
Abstrak: Kaki diabetes merupakan salah satu komplikasi kronik diabetes melitus yang sering dijumpai dan ditakuti oleh karena pengelolaannya sering mengecewakan dan berakhir dengan amputasi, bahkan kematian. Penanganan dengan debridemen tajam pada pasien dengan kaki diabetik merupakan baku emas tetapi masih dipertimbangkan akibat adanya gangguan metabolik, sepsis dan faktor komorbid lainnya. Penelitian ini bertujuan untuk menganalisis tindakan debridement tajam agresif dan konservatif pada pasien kaki diabetik dengan dinamika kadar IL-1 $\alpha$ dan hasil perbaikan klinis. Jenis penelitian ialah eksperimental analitik. Populasi penelitian ialah pasien kaki diabetik yang dirawat di RSUP Prof. Dr. R. D. Kandou Manado dengan rentang usia 30-60 tahun. Subjek penelitian diperoleh dengan simple random sampling, terdiri dari 38 pasien, dibagi atas dua kelompok: tindakan debridemen tajam agresif dan debridemen tajam konservatif, masing-masing 19 pasien. Pengumpulan sampel untuk pemeriksaan laboratorik dilakukan sebelum dan setelah masing-masing tindakan. Pada kelompok tindakan konservatif didapatkan rerata nilai IL-1 $\alpha$ sebelum tindakan ialah $108,158 \pm 14,519 \mathrm{pg} / \mathrm{ml}$ sedangkan setelah tindakan ialah 108,526 $\pm 16,625 \mathrm{pg} / \mathrm{ml}$ yang menunjukkan tidak terdapat peningkatan bermakna. Pada kelompok tindakan agresif nilai IL$1 \alpha$ sebelum tindakan ialah 93,263 $\pm 15,172 \mathrm{pg} / \mathrm{ml}$ sedangkan setelah tindakan ialah $104,052 \pm 18,807 \mathrm{pg} / \mathrm{ml}$ yang menandakan peningkatan bermakna. Simpulan: Peningkatan kadar IL- $\alpha$ setelah tindakan debrideman tajam agresif lebih besar dibandingkan setelah tindakan debrideman tajam konservatif pada penderita kaki diabetik.
\end{abstract}

Kata kunci: kaki diabetik, debridemen tajam, interleukin 1- $\alpha$ 
Infeksi pada kaki penyandang diabetes melitus (DM) merupakan penyebab morbiditas terpenting yang sering dijumpai di klinik-klinik umum dan merupakan indikasi untuk rawat inap karena penyembuhan luka tergantung perbaikan kadar gula darahnya. Kaki merupakan bagian tubuh yang paling sering terkena trauma ${ }^{1}$ Pada penyandang DM, trauma tersebut dapat disusul terjadinya luka dan menimbulkan komplikasi infeksi yang sulit sembuh sehinga membutuhkan perawatan lama dengan infeksi meluas pada kaki yang disebut kaki diabetik. ${ }^{2}$

Kaki diabetik merupakan salah satu komplikasi kronik DM yang sering dijumpai dan ditakuti oleh karena pengelolaannya sering mengecewakan dan berakhir dengan amputasi, bahkan kematian. ${ }^{3}$ Terjadinya kaki diabetik dapat dicegah dengan melakukan skrining dini dan edukasi pada kelompok berisiko tinggi, serta penanganan penyebab dasar seperti neuropati, penyakit arteri perifer, dan deformitas. Prevalensi kaki diabetik berkisar 4-10\% dari populasi umumnya, dengan prevalensi yang lebih tinggi pada manula. Penyandang DM memiliki risiko $15-25 \%$ dalam hidupnya untuk mengalami kaki diabetik yag pada 40-80\% kasus berkembang menjadi kaki diabetik. Diabetes melitus merupakan penyebab lebih dari 50\% amputasi nontraumatik di Amerika dan Eropa. ${ }^{4-6}$

Di negara maju, kaki diabetik masih merupakan masalah kesehatan yang besar. Dengan adanya perkembangan metode dan teknologi penatalaksanaan kaki diabetik serta klinik kaki diabetik maka angka kematian dan amputasi dapat ditekan. Di Indonesia, kaki diabetik masih merupakan masalah yang rumit dan tidak terkelola dengan maksimal. Selain itu, permasalahan biaya penelolaan yang besar menambah peliknya masalah kaki diabetik. ${ }^{3}$

Sitokin merupakan kelompok besar dari sinyal komunikasi seluler yang dapat memengaruhi aktivitas seluler pada proses inflamasi melalui jalur autokrin, parakrin, maupun endokrin. Sitokin berperan mengatur perkembangan respons imun dan inflamasi. Secara umum, sitokin dapat dikelompokkan ke dalam empat kategori sesuai dengan aktivitas inflamasi, yaitu pengenalan, pengikatan, penyingkiran, dan perbaikan. Salah satu sitokin yang berperan dalam pengenalan ialah interleukin-1 (IL1). ${ }^{7-9}$ Interleukin-1 disekresi oleh makrofag, monosit, dan sel-sel berinti lainnya. Sekresi tersebut distimulasi oleh antigen, toksin, kerusakan jaringan, dan inflamasi. ${ }^{10}$

Penanganan dengan debridemen tajam pada pasien dengan kaki diabetik merupakan baku emas dari penanganan tetapi masih dipertimbangkan dalam pelaksanaannya akibat dari gangguan metabolik pasien, sepsis dan faktor-faktor komorbid yang lain. Penelitian ini bertujuan untuk membandingkan kadar IL-1 $\alpha$ antara tindakan debridement tajam agresif dan debridement tajam konservatif pada penderita kaki diabetik. Hasil penelitian ini diharapkan dapat menjadi pertimbangan dalam penggunaan tindakan debrideman tajam konservatif pada kaki diabetik terutama pada pasien dengan komorbid untuk mencegah respon inflamasi akut.

\section{METODE PENELITIAN}

Jenis penelitian ini ialah analitik eksperimental untuk menganalisis tindakan debridement tajam agresif dan konservatif terhadap penderita kaki diabetik dengan dinamika kadar mediator radang yang dapat menyebabkan hasil perbaikan klinis dan evaluasi berdasarkan hasil pemerik-saan imunologi. Penelitian dilakukan di RSUP Prof. Dr. R. D. Kandou Manado sejak bulan Februari sampai September 2017.

\section{HASIL PENELITIAN}

Selama bulan Februari sampai September 2017 didapatkan 38 pasien kaki diabetik yang memenuhi kriteria inklusi dan menjadi sampel penelitian. Rerata usia pasien ialah 59 tahun dan sebagian besar yaitu 20 pasien $(52,6 \%)$ berjenis kelamin laki-laki. Rerata kadar IL-1 $\alpha$ sebelum perawatan ialah 108,158 $\pm 14,519 \mathrm{pg} / \mathrm{ml}$ pada kelompok dengan penanganan konservatif dan 93,263 $\pm 15,172 \mathrm{pg} / \mathrm{ml}$ pada kelompok dengan penanganan agresif. (Gambar 1). 


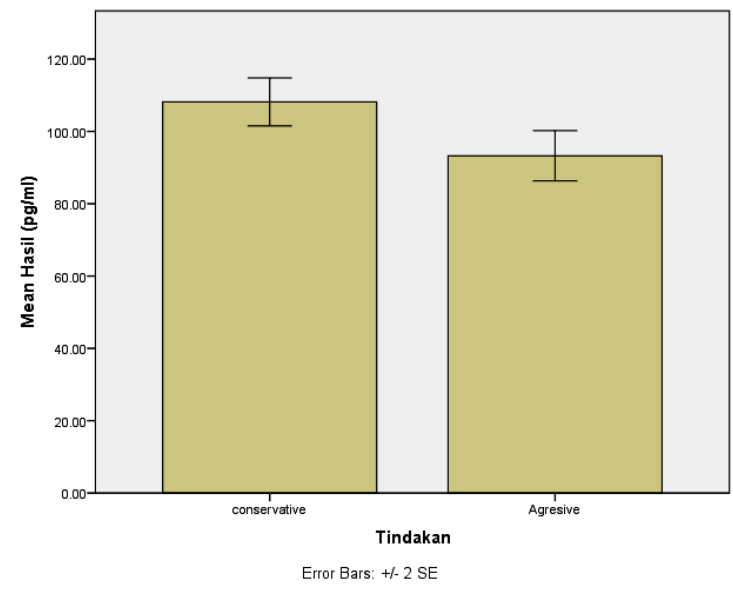

Gambar 1. Grafik rerata kadar IL- $1 \alpha$ sebelum tindakan debridement

Hasil uji statistik T tidak berpasangan dengan uji Levene untuk kesamaan variansi didapatkan nilai signifikansi 0,458 $(\mathrm{F}=0,562)>0,05$ yang mendukung asumsi variansi normal dengan sig. (2-tailed) $t$ (36) $=0,004<P=0,02$. Hal ini menyimpulkan asumsi tidak terdapat perbedaan kadar IL$1 \alpha$ yang bermakna saat sebelum perawatan.

Rerata kadar IL-1 $\alpha$ setelah perawatan $108,526 \pm 16,625 \mathrm{pg} / \mathrm{ml}$ pada kelompok dengan penanganan konservatif dan $104,052 \pm 18,807 \mathrm{pg} / \mathrm{ml}$ pada kelompok dengan penanganan agresif (Gambar 2).

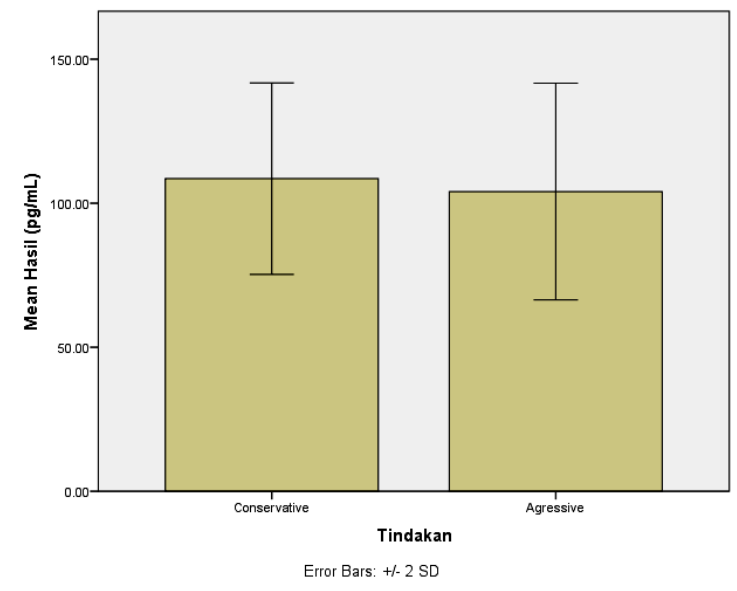

Gambar 2. Grafik rerata kadar Interleukin $1 \alpha$ setelah tindakan

Hasil uji statistik $\mathrm{T}$ tidak berpasangan dengan uji Levene untuk kesamaan variansi mendapatkan nilai signifikansi 0,424 $(\mathrm{F}=0,655)>0,05$ yang mendukung asumsi variansi normal dengan sig. (2-tailed) $t$ (36)
$=0,442>P=0,02$. Hasil uji $\mathrm{T}$ tersebut menunjukkan terdapat perbedaan bermakna antara kadar IL-1 $\alpha$ pada kelompok konservatif dan kelompok agresif setelah penanganan.

Rerata kadar CRP sebelum perawatan konservatif ialah $61,894 \pm 28,075 \mathrm{pg} / \mathrm{ml}$ dan $30,947 \pm 14,037 \mathrm{pg} / \mathrm{ml}$ setelah perawatan atau tindakan. Rerata kadar CRP sebelum perawatan agresif ialah 58,105 $\pm 31,308$ $\mathrm{pg} / \mathrm{ml}$ dan 27,158 $\pm 15,410 \mathrm{pg} / \mathrm{ml}$ setelah perawatan atau tindakan.

\section{BAHASAN}

Pada pasien kaki diabetik secara keseluruhan didapatkan perbedaan tingkat IL$1 \alpha$ sampai sebesar 38\%. Dari respons inflamasi lokal tersebut dapat berkelanjutan menjadi respons sistemik sebagai suatu respon trauma dimana terjadi pelepasan berbagai mediator pro dan anti inflamasi. ${ }^{11}$ Dari keseluruhan sampel yang dirawat secara agresif didapatkan respons inflamasi meningkat sedangkan yang diharapkan ialah tidak ada atau berkurangnya respons inflamasi baru agar dapat memulai proses penyembuhan. Pada pasien ulkus diabetik saat datang didapatkan rerata nilai IL- $1 \alpha$ untuk kedua kelompok tidak berbeda bermakna yang dibuktikan dengan uji Levene pada kedua kelompok pada saat sebelum dilakukan tindakan.

Interleukin-1 (IL-1 $\alpha$ ) idalah mediator proinflamasi utama pada peradangan akut dan kronis dan induser kuat respons imun alami. Produksi dan aktivitas IL- $1 \alpha$ diatur secara unik pada berbagai tingkat, dan konsentrasi IL-1 $\alpha$ eksogen yang sangat kecil dapat menginduksi sindrom dan syok seperti sepsis. IL-1 $\alpha$ menginduksi sintesis dan ekspresi beberapa ratus mediator peradangan sekunder, ${ }^{1,2}$ dan juga menginduksi produksi dan pengolahannya sendiri, dan langkah ini merupakan kunci dalam patogenesis berbagai penyakit autoinflamasi. ${ }^{1,3}$ Pada penelitian ini didapatkan bahwa IL-1 $\alpha$ berada dalam sirkulasi yang menandakan adanya proses inflamasi yang sedang berlangsung (ongoing) meskipun belum dilakukan tindakan.

Rerata kadar IL-1 $\alpha$ setelah perawatan 
ialah 108,526 $\pm 16,625 \mathrm{pg} / \mathrm{ml}$ pada kelompok dengan penanganan konservatif dan 104,052 $\pm 18,807 \mathrm{pg} / \mathrm{ml}$ pada kelompok dengan penanganan agresif. Pada uji statistik $\mathrm{T}$ tidak berpasangan dengan uji Levene untuk kesamaan variansi didapat nilai signifikansi $0,424(\mathrm{~F}=0,655)>0,05$ yang mendukung asumsi variansi normal dengan sig. (2-tailed) $t$ (36) $=0,442$ dimana lebih dari $P=0,02$ yang menandakan adanya perbedaan bermakna antara kedua kelompok. Sebelum tindakan didapatkan nilai rerata kadar IL-1 $\alpha$ 108,158 $\pm 14,519$ pg/ml dan kadar setelah tindakan 108,526 $\pm 16,625$ $\mathrm{pg} / \mathrm{ml}$ pada kelompok dengan penanganan konservatif, yang menunjukkan tidak terdapat peningkatan bermakna. Pada kelompok tindakan agresif awalnya kadar IL-1 $\alpha$ sebesar 93,263 $\pm 15,172 \mathrm{pg} / \mathrm{ml}$ menjadi $104,052 \pm 18,807 \mathrm{pg} / \mathrm{ml}$ yang menandakan terjadinya peningkatan bermakna.

Isoform IL- $1 \alpha$ menginduksi sintesis proIL-1 $\beta$ seperti halnya rangsangan proinflamasi lainnya antara lain agonis Tolllike receptor (misalnya, puing-puing sel atau produk bakteri). ${ }^{1,5}$ Selain itu, banyak potensi pemicu inflammasome telah diidentifikasi, termasuk antigen mikroba, sel yang hancur, ATP, iskemia, kristal kolesterol, dan lignan Toll-like receptor lainnya seperti pola molekul berbahaya atau pola molekuler patogen. ${ }^{4}$ Peradangan inflamasi setelah cedera jaringan menginduksi lonjakan lokal IL-1 $\beta$ yang secara bermakna menguatkan respon inflamasi, rekrutmen sel inflamasi lebih banyak, aktivitas metaloproteinase yang merangsang, dan akhirnya menyebabkan kematian sel inflamasi sel leukosit dan sel lainnya (piroptosis). ${ }^{12-14}$

Kepekaan terhadap stimuli dan intenitas serta durasi hasil respons inflamasi juga tergantung variasi genetik. Pada Cryopyrin-associated periodic syndromes suatu kelainan autoinflamasi kronis yang jarang terjadi, “senso" cryopyrin (NLRP3) yang pada dasarnya aktif, menye-babkan keadaan yang melemahkan dimana terjadi overprodusksi IL-1 $\beta .^{12}$ Poly-morphisme pada gen cryopyrin telah dikaitkan dengan kerentanan terhadap kelainan autoinflammasi. ${ }^{13}$ Polymorphisme pada kluster gen
IL-1 (yang mengkodekan IL-1 $\alpha$, IL-1 $\beta$, dan IL-1 receptor antagonist [IL-1Ra]) menyebabkan lebih banyaknya ekspresi agonis atau berkurangnya respons antagonis yang juga telah dikaitkan dengan onset prematur, meningkatnya keparahan penyakit, atau prognosis lebih buruk dari berbagai kondisi inflamasi, yaitu dari artritis reumatoid, periodontitis, inflammatory bowel disease, Alzheimer disease, dan lain-lainnya. ${ }^{14-16}$

Rerata kadar CRP sebelum perawatan ialah $61,894 \pm 28,075 \mathrm{pg} / \mathrm{ml}$ pada kelompok dengan penanganan konservatif dan $30,947 \pm 14,037 \mathrm{pg} / \mathrm{ml}$ setelah perawatan atau tindakan. Rerata CRP sebelum perawatan pada kelompok agresif ialah $58,105 \pm 31,308 \mathrm{pg} / \mathrm{ml}$ dan 27,158 $\pm 15,410$ $\mathrm{pg} / \mathrm{ml}$ setelah perawatan atau tindakan. Kadar CRP yang turun secara bermakna setelah perawatan menandakan bahwa terdapat penurunan respons inflamasi sistemik oleh karena kadar tetap CRP tergantung pada produksi oleh hepar. ${ }^{3}$

\section{SIMPULAN}

Pada penderita kaki diabetik didapatkan peningkatan IL-1 $\alpha$ yang lebih tinggi antara sebelum dan setelah dilakukan penanganan pada kelompok debridement tajam agresif dibandingkan kelompok debridement tajam konservatif.

Dapat diasumsikan bahwa debridement tajam agresif menyebabkan reaksi inflamasi yang lebih tinggi dibandingkan debridement tajam konservatif.

\section{SARAN}

Tindakan debridement tajam konservatif pada pasien dengan ulkus kaki diabetik dapat menjadi pertimbangan dalam melakukan penanganan terutama pada pasien dengan komorbid untuk mencegah respons inflamasi akut yang akan meningkatkan morbiditas.

\section{DAFTAR PUSTAKA}

1. Yuwono HHS. Ilmu Bedah Vaskular Sains dan Pengalaman Praktis. Bandung: Refika Aditama, 2010; p. 170.

2. Nurul EC. Gambaran kasus kaki diabetik dan pengelolaannya pada pasien rawat inap 
di rumah sakit dr. Hasan Sadikin Bandung periode 1 Januari 2000-31 Desember 2001 [Disertasi]. Bandung: Universitas Padjajaran; 2002.

3. Waspadji S. Kaki diabetes. In: Buku Ajar Ilmu Penyakit Dalam Jilid III (5th ed). Sudoyo AW, Setiyohadi B, Alwi I, Simadibrata MK, Setiati S, editors. Jakarta: Interna Publishing, 2009; p.1961-2.

4. Waniczek D, Kozowicz A, Muc-Wierzgon M, Kokot T, Swietochowska E, Nowakowska-Zajdel E. Adjunct methods of the standard diabetic foot ulceration therapy. Evidence-based complementary and alternative Medicine Hindawi. 2013;2013:1-12. Article ID 243568.

5. Langi YA. Penatalaksanaan ulkus diabetik secara terpadu. JBM. 2011;3(2):95-101.

6. Reiber GE, LeMasster JW. Epidemiology and economic impact of foot ulcers and amputations in people with diabetes. In: Browker JH, Pfeifer MA, editors. Levin and O'Neal's The Diabetic Foot (Seventh Edition). Philadelphia: Mosby Elsevier, 2008; p. 3-22

7. Maitra A, Abbas AK. The endocrine system. In: Robbins and Cotran Pathologic Basis of Disease (8th ed). Philadelphia: Elsevier Saunders. 2010; p. 1189-207.

8. Frykberg RG. Diabetic foot ulcers: pathogenesis and management. Am Fam Physician. 2002;66:1655-62.

9. Sjamsuhidajat R, De Jong W. Buku ajar Ilmu Bedah (3rd ed). Jakarta: EGC, 2004; p. 2-11.
10. Jeffcoate WJ, Hading KG. Diabetik foot ulcers. Lancet. 2003;261:1545-51.

11. Granick M, Boykin J, Gamelli R, Schultz G, Tenenhaus M. Toward a common language: Surgical wound bed preparation and debridement. Wound Repair Regen. 2006;14(Suppl 1):S1-10.

12. Cohen I, Rider P, Carmi Y, Braiman A, Dotan S, White MR, Voronov E, Martin MU, Dinarello CA, Apte RN. Differential release of chromatinbound IL-1alpha discriminates between necrotic and apoptotic cell death by the ability to induce sterile inflammation. Proc Natl Acad Sci. 2010; 107(6):2574-9.

13. Jennings PE, Belch JJF. Free radical scavenging activity of sulfonylureas: a clinical assessment of the effect of gliclazide. Metabolism. 2000;49(2 Suppl 1):S23-6.

14. LoGerfo FW. The diabetic foot. In: Dean RH, Yao YST, Brewster DC, editors. Current Diagnosis \& Treatment in Vascular Surgery (1st ed). Connecticut: Appleton \& Lange, 1995; p. 297-302.

15. Bowering CCK. Diabetic foot ulcers pathophysiology, assessment and therapy. Can Fam Phycisian. 2001; 47:1007-16.

16. Bouskela E, Bottino DA, Tavares JC. Microvascular permeability in diabetes. In: Schmid-Schonbein GW, Granger DN, editors. Molecular Basis for Microcirculatory Disorders. Paris: Springer-Verlag, 2003; p. 545-54. 